\title{
Front Matter: Volume 11754
}

, "Front Matter: Volume 11754," Proc. SPIE 11754, Sensing for Agriculture and Food Quality and Safety XIII, 1175401 (30 April 2021); doi: $10.1117 / 12.2598641$

SPIE. Event: SPIE Defense + Commercial Sensing, 2021, Online Only 


\section{PROCEEDINGS OF SPIE}

\section{Sensing for Agriculture and Food Quality and Safety XIII}

Moon S. Kim

Byoung-Kwan Cho

Editors

12-16 April 2021

Online Only, United States

Sponsored and Published by

SPIE 
The papers in this volume were part of the technical conference cited on the cover and title page. Papers were selected and subject to review by the editors and conference program committee. Some conference presentations may not be available for publication. Additional papers and presentation recordings may be available online in the SPIE Digital Library at SPIEDigitalLibrary.org.

The papers reflect the work and thoughts of the authors and are published herein as submitted. The publisher is not responsible for the validity of the information or for any outcomes resulting from reliance thereon.

Please use the following format to cite material from these proceedings:

Author(s), "Title of Paper," in Sensing for Agriculture and Food Quality and Safety XIII, edited by Moon S. Kim, Byoung-Kwan Cho, Proc. of SPIE 11754, Seven-digit Article CID Number (DD/MM/YYYY); (DOI URL).

ISSN: 0277-786X

ISSN: 1996-756X (electronic)

ISBN: 9781510643451

ISBN: 9781510643468 (electronic)

Published by

SPIE

P.O. Box 10, Bellingham, Washington 98227-0010 USA

Telephone +13606763290 (Pacific Time)

SPIE.org

Copyright @ 2021 Society of Photo-Optical Instrumentation Engineers (SPIE).

Copying of material in this book for internal or personal use, or for the internal or personal use of specific clients, beyond the fair use provisions granted by the U.S. Copyright Law is authorized by SPIE subject to payment of fees. To obtain permission to use and share articles in this volume, visit Copyright Clearance Center at copyright.com. Other copying for republication, resale, advertising or promotion, or any form of systematic or multiple reproduction of any material in this book is prohibited except with permission in writing from the publisher.

Printed in the United States of America by Curran Associates, Inc., under license from SPIE.

Publication of record for individual papers is online in the SPIE Digital Library.

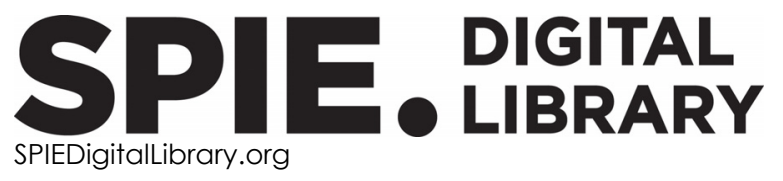

Paper Numbering: A unique citation identifier (CID) number is assigned to each article in the Proceedings of SPIE at the time of publication. Utilization of CIDs allows articles to be fully citable as soon as they are published online, and connects the same identifier to all online and print versions of the publication. SPIE uses a seven-digit CID article numbering system structured as follows:

- The first five digits correspond to the SPIE volume number.

- The last two digits indicate publication order within the volume using a Base 36 numbering system employing both numerals and letters. These two-number sets start with 00, 01, 02, 03, 04, 05, 06, 07, 08, 09, 0A, OB ... 0Z, followed by 10-1Z, 20-2Z, etc. The CID Number appears on each page of the manuscript. 


\section{Contents}

NIR SPECTROSCOPY

$1175402 \quad$ Near infrared methodology for growth monitoring of spinach plants in the field [11754-1]

$1175403 \quad$ Classification by bitterness of intact almonds analysed in bulk using NIR spectroscopy [11754-2]

$1175405 \quad$ Evaluation of olive oil quality using a miniature spectrometer: a machine learning approach [11754-4]

\section{RAMAN SPECTROSCOPY AND IMAGING}

$1175408 \quad$ Near-infrared hyperspectral imaging for identification of aflatoxin contamination on corn kernels [11754-7]

\section{HYPERSPECTRAL IMAGING}

$11754 \mathrm{OB} \quad$ Hyperspectral imaging for the determination of the main unsaturated fatty acid distribution in shelled almonds analysed in bulk [1 1754-10]

\section{UAV-BASED IMAGING}

$11754 \mathrm{OF} \quad$ Accuracy and reliability of predictions of $E$. coli concentrations in water of irrigation ponds from drone-based imagery as affected by parameters of the random forest algorithm [1 1754-14]

11754 OG UAV-based agricultural monitoring and data acquisition system for precision farming [11754-15]

\section{BIOSENSING}

11754 OK Towards a field deployable pathogen detection system by quartz-crystal microbalance [11754-18] 
POSTER SESSION

1175400 Spatial scattering Raman spectral characteristics of clenbuterol [1 1754-22]

$117540 Q$ Hazelnuts classification by hyperspectral imaging coupled with variable selection methods [11754-24] 